\title{
The Clergy of the Archdiocese of Lviv of the Latins in Aid of the Jewish Nation during the Years of the German Occupation from 1941-1944. An Outline of the Events
}

\begin{abstract}
During the German occupation, large numbers of Poles were actively involved in assisting the persecuted Jews. Among the Poles who extended help were also priests from the Archdiocese of Lviv of the Latins. This article addresses their assistance and protection of the many Jews who were being persecuted by the German Army. Certainly, it does not exhaust the subject, but constitutes some contribution to ongoing research. It is not an easy undertaking, since the sources are extremely scanty, and the search for any information is both a time and labor consuming occupation. Still, given the information gathered here, we are given an opportunity to discern a certain image of clergymen who unhesitatingly sacrificed themselves to save the lives of people who were followers of a different faith. Two priests laid down their lives in the process.
\end{abstract}

\section{Keywords}

Archdiocese of Lviv of the Latins, Lviv, Jews, Eastern Małopolska Province, Holocaust, clergy.

As a result of the Ribbentrop-Molotov Pact of 23 August 1939, the German occupation of the lands of the Second Polish Republic occurred in September of that year. The occupation included the lands to the west of the boundary contractually demarcated along the rivers of Narew, Vistula and San. Following the German invasion of the Soviet Union in June of 1941, the area under occupation was extended over further eastern territories of the prewar Poland. It was only then that the Archdiocese of Lviv of the Latins fell within the boundaries of the Third Reich. In the newly conquered territories, 


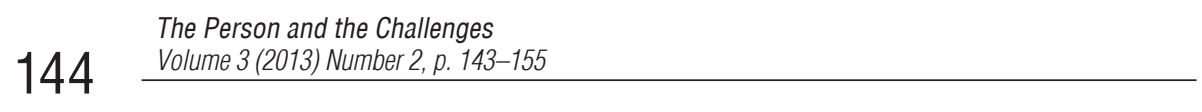

the new Nazi occupying forces immediately began the extermination of the Jewish people resorting to the methods which had already been tried on the General Government. The territories of the three pre-war provinces of southeastern Poland - the Lviv, the Stanislaviv and the Ternopil one - came to form the District of Galicia, whose authorities painstakingly followed the Nazi guidelines. That state of affairs continued until the summer of 1944 when the Red Army drove the Germans out of the lands of the Archdiocese of Lviv.

During this period of time, the Polish population of the Eastern Borderlands was forced to gather as a community and defend all who were in harms way. On the one hand, they had to take care of their own safety -- threatened by the German Security Service -- and on the other hand, they were forced to defend all life against the growing and uncommonly violent acts of extermination conducted by the Ukrainian nationalists. Living under inescapable threat, the Poles somehow found the means to undertake efforts aimed at saving the Jewish people who were being mass-murdered by the German Nazis. Poles somehow found the means to undertake efforts aimed at saving the Jewish people who were being mass-murdered by the German Nazis supported by the Ukrainians. The clergy also came to the aid of Jewish believers and just like all the Poles, they themselves were threatened with death for any attempts to help the Jews.

In the case of the Archdiocese of Lviv of the Latins, the historical reconstruction of the Jewish peoples rescue campaign by the clergy turns out to be an extremely challenging assignment. Attempts to gather facts and data are thwarted by the death of any witnesses that might corroborate the clergymen's involvement in the process. A search conducted at the Archive of the Lviv Metropolitan Curia in $\mathrm{Cracow}^{1}$, where the Second World War archive is, turned up few if any relevant records. In the 'reminiscence database' for the Archdiocese of Lviv during the Second World War, the greatest number of accounts is concerned with the slaughter committed by the Ukrainian nationalists of the Polish people, including priests, and particularly in the years 1943-1945. Also, from the point of view of the biographies of selected priests, the authors focus mainly on their own lives and the reality experienced under

\footnotetext{
1 This archive is also called the Archbishop Eugeniusz Baziak Archive. In June 2012 by decision of the Archbishop of Lviv Mieczysław Mokrzycki it was put in safe deposit at the Pontifical University of John Paul II in Cracow.
} 
German occupation ${ }^{2}$. For these above-mentioned reasons they circumvent the Jewish issue, which is of interest to us.

The issue of helping Jews, which is to be the focus of our discussion here, concerned the whole of the Latins Rite clergy, not excluding the uppermost echelons, and including Archbishop Bolesław Twardowski ${ }^{3}$. The hierarch himself joined in the campaign, giving shelter to Dr Władysław Elmer ${ }^{4}$ and his family ${ }^{5}$ at his Archbishop's Palace in Lviv. However, this fact was not accidental, since as early as in the interwar period the doctor, as an internal medicine specialist, along with another academic, Prof. Wincenty Czernecki, treated the metropolitan (His Excellency), who suffered from diabetes. As of July 1941 the doctor's capacity was different. As the preserved documents testify ${ }^{6}$, he was a Lviv Jew, christened in 1923.

Dr. Elmer was brought over to the Archbishop's Palace by the chancellor of the Lviv Metropolitan Curia, Rev. Zygmunt Hałuniewicz in July of 1941. It was during the absence of the Archbishop, who at that time was on holiday in the village Rodatychi near Lviv. After his return, the hierarch accepted the new resident, but today even with hindsight it is difficult to establish

2 J. Anczarski, Kronikarskie zapisy z lat cierpień i grozy w Małopolsce Wschodniej 1939-1946, ed. J. Wołczański, Lwów-Kraków 1998²; W. Szetelnicki, Parafia rzymsko-katolicka w Stobódce Dżuryńskiej, Roma 1979; Idem, Zapomniany lwowski bohater ks. Stanisław Frankl (1903-1944), Roma 1983; Idem, Arcybiskup-wygnaniec Eugeniusz Baziak metropolita lwowski, Kraków 1989; Idem, Podolski Vianney ks. Teodor Kasperski twórca kalwarii w Winiatyńcach, Kraków 1990.

3 Bolesław Twardowski (1864-1944) was ordained in Lviv in 1886, a doctor of canon law, a chancellor of the Metropolitan Consistory in Lviv 1895-1902, a parish priest of Our Lady of Perpetual Succor parish in Ternopil 1902-1918, a canon of the Metropolitan Chapter in Lviv 1918-1923, an assistant bishop of the Lviv Archdiocese 1919-1923, Metropolitan Archbishop of Lviv 1923-1944. G. Chajko, Arcybiskup Bolesław Twardowski (1864-1944) metropolita lwowski obrządku łacińskiego, Rzeszów 2010, passim.

4 Artur (Władysław) Elmer - b. 1 February 1899 in Lviv, in the years 1906-1911 a pupil at St. Anna and Adam Mickiewicz primary schools in Lviv, a 1918 graduate of Jan Długosz middle school in Lviv, a graduate of the Faculty of Medicine of John II Casimir University in Lviv in 1923, later an academic at the same Faculty; in 1918 a volunteer for the Polish Army. G. Chajko, Arcybiskup Bolestaw Twardowski, p. 386.

5 The doctor took up his residence with his wife and two children aged 10 and 15 . The son's name was Janusz.

6 At the Archive of the Lviv Metropolitan Curia in Cracow (hereinafter ALKMK) there is a collection of a few documents dated 1923 which certify that Dr Władysław Elmer was christened. These include a CV, a baptism application, Rev. Stanisław Sokołowski's opinion, a copy of the entry made in the register of denomination changes at the Municipal Office of Lviv. ALKMK, Consistory Documents, catalogue no. 857, [A collection of documents concerned with the baptism of Władysław Elmer], Lwów 1923. 
whether the new resident had not been brought over at the landlord's request. Whatever the circumstances, the Elmer's were given suitable rooms. The doctor took the ground floor room, and on the third floor was his study, where he did medical examinations and experiments. The laboratory housed a radio station, where the doctor was frequently visited by representatives of the Polish Underground State?

Despite the fact that the doctor and his family did not leave their accommodation for a few months at a time, after two years of living in hiding, their family became victims of a terrible occurrence. On 8 August 1943, the Elmer's youngest son Janusz, went out to collect the morning milk delivery from the caretaker who lived at 5 Teatyńska Street. While Janusz was there visiting, Gestapo officers entered the apartment and upon discovering a young man with distinctly Semitic features, they asked him about his place of residence. After he had pointed to the Archbishop's Palace, they escorted him there to investigate. As they were walking down the Palace corridor, Dr. Elmer walked out of his apartment and encountered the German officers. They immediately demanded to see his identification papers. Dr. Elmer was carrying false documents made out in the name of 'Teodorowicz'. As they remarked sneeringly about the spelling the surname, the doctor went into a panic and started running for his life. He stormed out of the building and as he was heading for St Casimir's church, he was shot. Soon, German troops arrived, and the whole Elmer family was taken away. The doctor was rushed to hospital, having received last sacraments, he succumbed to his injuries. The family members were taken to Lysynychi near Lviv ${ }^{8}$ and executed.

As mentioned before, in accordance with the Nazi law, providing shelter to Jews was forbidden on pain of death. However, in this particular case Archbishop Twardowski did not suffer any repressive measures. His personal secretary Rev. Mieczysław Marszalik left Lviv destined for Rava Ruska, and in doing so, diverted the attention away from the Archbishop. Before his trip he ordered that, in case of any trouble, all the blame for the situation should be shifted onto him. In hindsight although this was a valiant act, it was not necessary ${ }^{9}$.

7 G. Chajko, Arcybiskup Bolestaw Twardowski, pp. 387-389.

8 Ibidem, pp. 387-388; S. Bizuń, Historia krzyżem znaczona. Wspomnienia z życia Kościoła katolickiego na Ziemi Lwowskiej 1939-1945, ed. J. Wołczański, Lublin 1994², pp. 187-189.

9 G. Chajko, Arcybiskup Bolesław Twardowski, p. 388. 
It is a matter of conjecture why appropriate measures were not taken by the Germans against the Archbishop. Some would state that it was because of his advanced age; others would refer to the fact that the occupying forces made quite a profit from the death of the convert - the gold that the deceased kept in his apartment, which was twice ransacked would provide a small fortune. It is also thought that the old and ailing Archbishop Twardowski appeared not to be aware of the impending danger. Whenever Dr. Elmer warned him of dangers, he would say: "He [Dr. Elmer] saved my life"10.

A few days later the above-mentioned Rev. Marszalik, as he was travelling by train, learned about it from a German carrying out a check. The news quickly reached the distant city of Ternopil ${ }^{11}$. The story of the clergymen from the Archdiocese of Lviv of the Latins helping a Lviv Jew was one of the bestknown cases talked about during the war in Eastern Małopolska.

Due to his ailments, Archbishop Twardowski was not actively involved in the aid to the Jewish people, but on the other hand his knowledge and support of such cases cannot be refuted. Still, priests from the Lviv parishes distinguished themselves by very active involvement in the relief work provided for the Jewish people. Because of the size of the diocese and the fact that in the interwar period it was inhabited by numerous Jewish Diaspora communities, Lviv afforded substantial opportunities for aid. The clergymen's activity chiefly consisted in making out fake baptism certificates, which served as tickets to salvation. The scale of this phenomenon was so great that might not be able to be reconstructed today.

Among the Lviv parishes, the one that was certainly involved in creating documents was St Nicholas Parish. The campaign was led by Rev. Kazimierz Gumol, Rev. Władysław Makarczuk and Rev. Franciszek Siekierski. As a cover-up, they resorted to the late Rev. Franciszek Janicki so that in case of trouble they could shift the blame onto the deceased ${ }^{12}$. They also administered baptism to applicants, as records show that on 30 September 1941, a young Jewish girl, Zofia Spatz, who was raised in a Catholic home had received her baptism into the Church $^{13}$.

10 Ibidem.

11 Ibidem.

12 ALKMK, K. Gumol, Wspomnienia do 1939 r., part 2, Nysa 1981, mps, no catalogue number, passim.

13 S. Bizuń, Historia krzyżem znaczona, pp. 125-126. 
In the Lviv monastic parishes the situation was similar. For instance, the parish of the St. Vincent de Paul Congregation of the Mission provided religious education for the Jews with a intention of preparing them for baptism. The meetings enjoyed unswerving interest. The Superior Rev. Stanisław Kałężny made the following entry for 2 July 1941: "Large numbers of Jews are applying for baptism. There were 50 applications at St Vincent Parish within one week; formerly there were 4 or 5 within one year" ${ }^{\prime \prime}$.

In the process of rescuing Jews not all the clergymen were as lucky as Archbishop Twardowski. At least two of the priests of the Lviv Archbishopric were killed in retaliation for this activity. These were Rev. Edward Tabaczkowski ${ }^{15}$-a parish priest in the town of Tlumach ${ }^{16}$, and Rev. Franciszek $\dot{Z}_{\mathrm{ak}}{ }^{17}$ - a curate in the town of Dolyna ${ }^{18}$. The former can be reckoned among the priests-community workers, particularly sensitive to the fate of the poor and the needy. As early as during the First World War, within the Tlumach parish, he set up an orphanage for 70 war orphans, and in the interwar period - a hall of residence for pupils, and a home for the retired. Rev. Edward Tabaczkowski was a kind and compassionate man who sought out the needy within the vicinity, irrespective of their walks of life. In the period of the Soviet occupation (1939-1941) he was in correspondence with the people exiled to Siberia, showed genuine interest in their fate, was in charge of the dispatch of aid parcels, and celebrated Holy Masses for their intention. Publicly, from the pulpit he would read letters from the exiled parishioners to the congregation.

14 The Archive of the Polish Province of the Congregation of the Mission in Cracow, House No. 20 of the Vincentians in Lviv, I - History Materials, 5a - Liber Memorabilium (1919-1942) - Chronicle of the Lviv House of St. Vincent de Paul Congregation of the Mission (1919-1946), p. 214.

15 Edward Tabaczkowski (1872-1942), he took holy orders in Lviv in 1898, a curate at the parish in Mykulyntsi 1898-1902, a curate at the parish in Skalat 1902-1903, a parish priest in Kukisov 1903-1910, a parish priest in Tlumach 1910-1942. Schematismus [Elenchus] archidioecesis Leopoliensis ritus latini 1898-1939, passim; Schematyzm archidiecezji w Lubaczowie 1981 r., Lubaczów 1981, p. 128.

16 Tlumach - a county city, Stanislaviv Province.

${ }_{17}$ Franciszek Żak (1901-1942), he took holy orders in Lviv in 1925, a curate at the parish in Verkhnya Bilka 1925-1926, a parish catechist in Skalat 1927-1929, a parish catechist in Horodok [Gródek Jagielloński] 1930-1932, a parish administrator in Ponykva 1933-1935, an administrator and catechist at the parish in Ponykva 1936-1938, a catechist at the parish in Dolyna 1939-1942. Schematismus [...] 1925-1939, passim.

${ }^{18}$ Dolyna - a county city, Stanislaviv Province. 
Working on the Christian principle of helping the poor, he sold his house to the Soviets, and gave the proceeds to the most needy parishioners ${ }^{19}$.

Rev. Edward Tabaczkowski's experiences during the Second World War were dear to him and particularly during the German occupation of the Eastern Borderlands. It was there that he took the Jews under his care and provided them with aid and comfort. In the autumn of 1942 he took on a Jewish student by the name of Leon Weiser. Leon had arrived at the parish office of the Tlumach presbytery requesting if there might be assistance available to protect him. It was here that the frightened student received his greatest gift and eternal passport in the sacrament of baptism from Rev. Tabaczkowski. During the days he stayed at the presbytery, and in the evening he would go to the Falstiger's residence, who had declared themselves Volksdeutsche. In the interest of protecting Leon, this plan was not successful as he was eventually arrested and executed in the prison in Stanislaviv. This fact did not prove insignificant for the Tlumach parish priest, for it was soon thereafter that the local Gestapo took an interest in his activity. The parishioners advised Rev. Tabaczkowski to leave the parish as soon as possible. Like a good shepherd he was not going to leave his flock. A few days after the execution of Leon Weiser, he too was apprehended and put away in a prison located in Stanislaviv. Tormented by the torturers, he was killed most probably on 20 October $1942^{20}$.

Among the priests assisting the Jews was also Rev. Stanisław Mazak ${ }^{21}$. During the Second World War the Reverend performed his pastoral duties in the parish of Shchurovychi ${ }^{22}$. His services rendered for the said cause were honored with the title of the Righteous among the Nations, which was conferred

${ }^{19}$ J. Krętosz, Tabaczkowski Edward, in: Stownik biograficzny duchowieństwa metropolii lwowskiej obrzadku lacińskiego ofiar II wojny światowej 1939-1945, ed. J. Krętosz, M. Pawłowiczowa, Opole 2007, p. 154; W. Urban, Archidiecezja lwowska, in: Życie religijne w Polsce pod okupacja 1939-1945. Metropolie wileńska i lwowska, zakony, ed. Z. Zieliński, Katowice 1992, pp. 126, 154.

${ }^{20}$ J. Krętosz, Tabaczkowski Edward, in: Stownik biograficzny, pp. 154-155; „Na Rubieży” (1998), no. 30, p. 37; W. Urban, Archidiecezja lwowska, pp. 154-155.

${ }^{21}$ Stanisław Mazak (1906-1988), he took holy orders in Lviv in 1933, a parish catechist in Barysh 1933-1935, a parish administrator in Porchova 1935-1940?, a curate at the parish in Shchurovychi 1940?-1943, an administrator in 1943-1945. Expatriated, he left for Opole Silesia; a parish priest in Kamiennik and ex currendo Gaworowice 1945-1947, a parish priest in Świętów Polski 1947-1973, retired 1973-1988. He died 23 April 1988 in Świętów Polski. J. Wołczański, Eksterminacja narodu polskiego i Kościoła rzymskokatolickiego przez ukrainskich nacjonalistów w Małopolsce Wschodniej 1939-1945. Materiały źródtowe, Part 1, Kraków 2005, p. 68.

${ }^{22}$ Shchurovychi - a city in the Radekhiv county, Ternopil Province. 
upon him by the Yad Vashem Institute in Jerusalem on 16 February 1984. His extraordinary activity is probably best reflected in the entry in the Book of the Righteous: "Stanisław Mazak, a Roman Catholic priest, was the spirit behind the campaign to save a group of Jews from the village of Shchurovychi (Radziechów county, Ternopil district). In his sermons during Holy Mass in the local church, Father Mazak would call upon the faithful to take part in saving the persecuted, trying to convince them to do what they could, even at the cost of self-sacrifice. And indeed, the much admired Father Mazak's flock responded to his appeal and extended their assistance to the Jews who were hiding in the area. Under Reverend Mazak's influence, even farmers who did not personally hide Jews in their homes volunteered to help, providing food and keeping their hiding places secret from their Ukrainian nationalist neighbors. Reverend Mazak himself visited the hiding places, offering comfort by cheering up the Jewish fugitives and providing them with medicine as needed. In one documented case, the priest provided Scharlota Weksler and her son with Aryan papers, accompanied them to Cracow, and after learning that the mother had been sent to forced labor in Germany, he moved her son to a Catholic children's home in Warsaw, where his life was saved. After he was warned of the danger to his life, the priest managed to flee from his village. He hid out in the nearby city of Łopatyn and after the war moved to Upper Silesia. In early 1944, Ukrainian collaborators learned of Reverend Mazak's efforts to save Jews, arrested him and had him sentenced to death ${ }^{23}$.

The case of Rev. Mazak is by no means an isolated one. There are also many priests from other Polish dioceses as well as nuns on the Israeli Institute list.

Another example would be of Rev. Stanisław Falkowski. During the Second World War, when he was a parish priest in Piekuty Nowe (Wysokie Mazowieckie County), he took in a Jew who had escaped from a train bound for the extermination camp in Treblinka. During a period of four months the priest supported him. Then, he provided him up with Aryan papers, facilitated his departure as a volunteer to forced labor in the Third Reich, thus aiding to save his life ${ }^{24}$. Another clergyman, Rev. Feliks Gloeh, a pastor of the Evangelical Church of the Augsburg Confession, along with a friend, Dr Michał Lityński,

${ }^{23}$ Księga Sprawiedliwych wśród Narodów Świata. Ratujący Żydów podczas Holocaustu. Polska, vol. 1, ed. I. Gutman, Kraków 2009, p. 451.

${ }^{24}$ Ksiega Sprawiedliwych, pp. 161-162. 
produced false certificates of non-Jewish origin, and the doctor provided medical care at a nearby hospital and aided refugees at a safe shelter ${ }^{25}$.

Rev. Aleksander Oberc, the curate of the parish in Hodovytsia near Lviv (1938-1943) and in Zhovkva (1943-1945) ${ }^{26}$. Still, that does not downgrade his services rendered in the fight against the occupying forces, as he served as a chaplain of the Home Army and actively helped to save lives of the oppressed Jewish nation ${ }^{27}$.

Listed within the secular biographical entries in the Book of the Righteous, are passages regarding other Lviv Archdiocese priests who in an unknown way, often symbolically or as intermediaries, joined in the conspiratorial action. One of these such records concerns the rescue of a Jew, Maksymilian Doll and his family, who decided to go into hiding after the massacre of 1942 carried out by the Germans and Ukrainians in Zboriv. They were helped out by the local parish priest Rev. Jan Pawlicki, who made out false documents and arranged their relocation to Berezhany. Once safely located in Berezhany, Mr. Doll found employment with the help from his friend Karol Bogucki, who introduced him to his acquaintances ${ }^{28}$.

In another case, eighteen-year-old Chana Landau who as the only one from her family to survive, went to the parish church in Vynnyky near Lviv, obtained Aryan papers made out in her friend's name, returned to her home town, and then left for $\mathrm{Cracow}^{29}$. This account does not mention the name of the clergyman who extended the help, but given the place, name and historical information, we can surmise that that might have been the parish priest Rev. Antoni Saczyński (d. 16 October 1941) or his successor, the administrator Rev. Albin Mydlar, or possibly the catechist Rev. Władysław Pelc ${ }^{30}$.

Rev. Jan Winiarski from the Lviv Archdiocese also served fearlessly in the history of the rescue of Jews from total extermination. Soon after the outbreak

${ }^{25}$ Ibidem, pp. 185-186.

${ }^{26}$ E.g.: Oberc Aleksander, www.web.archive.org/web/20080527201619/http://www.jaslanie. gal.pl/o_slow.html (20.03.2013); Ks. Aleksander Oberc, kapelan AK, www.katolicy.eu/PRL/Oberc. htm (20.03.2013).

${ }^{27}$ Ibidem.

${ }^{28}$ Księga Sprawiedliwych, p. 54.

${ }^{29}$ Ibidem, pp. 71-72.

${ }^{30}$ Schematismus [...] 1939, Leopoli 1939, pp. 30-31; Schematismus [...] 1943, Leopoli 1943, p. 11; Schematyzm archidiecezji w Lubaczowie, p. 127. 
of the Second World War and serving as a curate, he was transferred from the Zabolotiv parish to the Nadvirna parish ${ }^{31}$.

The local presbytery turned out to be a strategic facility on the map of underground activity; it was a courier redeployment point and an organization hub for the resistance movement. Escapees from POW camps and Jews who had successfully fled from the round-ups staged in city streets found refuge there. Rev. Winiarski took active part in the operation and "even without the parish priest's knowledge, concealed Jews who had escaped from the Hungarian army. At night he would bring them food and water until the time when the town was seized by the Soviet troops" 32 .

Rev. Winiarski who died of typhus in the Stanislaviv prison in 1942 was also involved in the charitable work of providing aid to the Jews. He organized the dispatch of aid parcels to Polish families deported into the interior of Russia, supported and helped Jews and managed a mail station redeploying couriers between the occupied country and the government of the Polish Republic"'33.

In regards to the roles of other priests, the predominant form of aid was the issuance of false baptism certificates. For instance, a curate from Ternopil, Rev. Adolf Iwańciów, issued a Jewish man with a baptism certificate of a deceased Catholic woman. When the Gestapo stopped him for questioning, they were not able to prove anything and so they let him off. An administrator of the parish in Kokutkivci ${ }^{34}$, Rev. Jan Kucy, was also involved in this charitable practice. Within his means he did his best to issue false certificates ${ }^{35}$.

Rev. Julian Rudnicki, a parish priest from Kukisov ${ }^{36}$ also issued baptismal certificates to Jews, deserters and gypsies. He supplied food to the Jews imprisoned in the camp in Novyj Jarychiv ${ }^{37}$. Healso supported the regional structures of the Home Army, and managed distribution of an underground press" ${ }^{\prime 38}$.

${ }^{31}$ Nadvirna - a county city, Stanislaviv Province.

${ }^{32}$ M. Skórniak, Kresowe pielgrzymki, „Spotkania Świrzan” (2007), no. 71, p. 35; W. Urban, Archidiecezja lwowska, p. 157.

${ }^{33}$ M. Zalotyński, † Smaczniak Józef ps. Nadworny, www.mielec.rzochow.diecezja.tarnow.pl/ index.php?id=duszpasterze \&sub=Pochodz $\% C 4 \% 85 \&$ (20.03.2013).

${ }^{34}$ Kokutkivci - a village in the Ternopil county, Ternopil Province.

${ }^{35}$ W. Urban, Archidiecezja lwowska, p. 156.

${ }^{36}$ Kukisov - a city in the Lviv county, Lviv Province.

${ }^{37}$ Novyj Jarychiv - a city in the Lviv county, Lviv Province.

${ }^{38}$ Ks. Julian Rudnicki, działacz narodowy, www.katolicy.eu/ZSRR/Rudnicki\%20Julian.htm (21.03.2013). 
Rev. Franciszek Jastrzębski stated that "Only a few individuals have survived. For instance, at my place there was one Jewish woman, who was referred to me by Rev. Stefan Chabło from Velykyi Khodachkiv near Ternopil; she was taken on at the presbytery as a domestic help; she survived, and even managed to have a Kennkarte made out with a false name. [...] Another Jewish woman, a daughter of a local owner of the lands remaining from the manor farm, was also a survivor at my place. She stayed hidden in a stack of straw in summer and winter where my sister supplied her with food. When she left the hideout in 1944, she hardly resembled a human being. Both these Jews came out after the arrival of the Soviets on 22 July $1944^{39}$. Also the parishioners rescued her sister since she did not have any Semitic features. Moreover, thanks to the help provided by the people, two local Jews survived, hiding in lofts" ${ }^{\prime 40}$.

The number of Jewish people who owe their lives to clergymen, not only from the Archdiocese of Lviv of the Latins, but throughout Europe is certainly great, and it cannot be covered within this article, but we must take a broader view of it. Above all, undertaking the effort, the priests were guided by the evangelical principle of love for their neighbor, irrespective of his nationality or creed. Undoubtedly, their conduct and care for the fate of fellow human beings issued from the convictions and the belief that their endeavor was aimed at the protection of the highest values. It can also be assumed that some of them experienced fear for their health and lives; however, on the other hand, there may still have been vivid memories of national-religious antagonism from the interwar period, which divided the Poles and Jews at that time.

The process of rescuing Polish Jews from the Holocaust can probably be best rendered with the aid of the data from the Yad Vashem Institute in Jerusalem. Here they estimate that after the Second World War there were $300,000-350,000$ Jewish survivors, which amounts to around $10 \%$ of the prewar community in Poland. From this number, only around 50,000 were saved in the occupied country, 15,000 of which were liberated from camps, whom Germans did not take time to evacuate to Germany, or who lived to be

${ }^{39}$ In the original text on the website, the last two sentences preceding this footnote feature the year 1945, which seems to be a factual mistake, since the Jews would come out of their hideouts right on the Soviet invasion of the Eastern Borderlands of the Second Polish Republic, not waiting for the war to end, which is the contingency that the author of the text seems to be pointing to.

40 Wspomnienie z życia ks. Franciszka Jastrzębskiego 1890-1962 (obszerne fragmenty), www. kresowianiezkuropatnik.republika.pl/wspomnienieks.html (21.03.2013). 
liberated. A few thousand Jews managed to escape to the Eastern Borderlands of the Second Polish Republic, where they huddled in forests, forming survival groups, or stayed with local families. Many of them were also active in the fight against the German invaders by joining Polish guerrilla groups. The same source devoted to the research into the history of the Holocaust victims affords information of 30,000 - 35,000 Jews being saved thanks to the Polish people's involvement ${ }^{41}$.

The majority of those Poles who sacrificed their health, and not infrequently, their lives, have remained anonymous. Only some of them have been immortalized, having their names mentioned on the pages of memory and history. The oft-mentioned Yad Vashem Institute has so far honored more than 6,300 Poles with the title of the Righteous among the Nations.

The subject of the rescue of Jews by the priests from the Archdiocese of Lviv can serve as another contribution to the study of the history of the Church and the difficult years of the Second World War in the Eastern Borderlands of the Second Polish Republic.

\section{Bibliography}

\section{Archives}

The Archive of the Lviv Metropolitan Curia in Cracow, Consistory Documents, catalogue no. 857 [A collection of documents concerned with the baptism of Władysław Elmer], Lwów 1923.

The Archive of the Lviv Metropolitan Curia in Cracow, K. Gumol, Wspomnienia do 1939 r, part 2, Nysa 1981, mps, no catalogue number.

The Archive of the Polish Province of the Congregation of the Mission in Cracow, House No. 20 of the Vincentians in Lviv, I - History Materials, 5a - Liber Memorabilium (1919-1942) - Chronicle of the Lviv House of St. Vincent de Paul Congregation of the Mission (1919-1946).

\section{Printed sources}

Anczarski J., Kronikarskie zapisy z lat cierpień i grozy w Małopolsce Wschodniej 19391946, ed. J. Wołczański, Lwów-Kraków 1998.

Bizuń S., Historia krzyżem znaczona. Wspomnienia z życia Kościoła katolickiego na Ziemi Lwowskiej 1939-1945, ed. J. Wołczański, Lublin 1994².

Schematismus [Elenchus] archidioecesis Leopoliensis ritus latini 1898-1939.

Schematyzm archidiecezji w Lubaczowie 1981 r., Lubaczów 1981.

\footnotetext{
${ }^{41}$ Księga Sprawiedliwych, p. XIX.
} 
Wołczański J., Eksterminacja narodu polskiego i Kościoła rzymskokatolickiego przez ukraińskich nacjonalistów w Małopolsce Wschodniej 1939-1945. Materiaty źródłowe, Part 1, Kraków 2005.

\section{Development}

Chajko G., Arcybiskup Bolestaw Twardowski (1864-1944) metropolita lwowski obrzadku tacińskiego, Rzeszów 2010.

Księga Sprawiedliwych wśród Narodów Świata. Ratujący Żydów podczas Holocaustu. Polska, vol. 1, ed. I. Gutman, Kraków 2009.

Słownik biograficzny duchowieństwa metropolii lwowskiej obrządku łacińskiego ofiar II wojny światowej 1939-1945, ed. J. Krętosz, M. Pawłowiczowa, Opole 2007.

Szetelnicki W., Parafia rzymsko-katolicka w Słobódce Dżuryńskiej, Roma 1979.

Szetelnicki W., Zapomniany lwowski bohater ks. Stanisław Frankl (1903-1944), Roma 1983.

Szetelnicki W., Arcybiskup-wygnaniec Eugeniusz Baziak metropolita lwowski, Kraków 1989.

Szetelnicki W., Podolski Vianney ks. Teodor Kasperski twórca kalwarii w Winiatyńcach, Kraków 1990.

Urban W., Archidiecezja lwowska, in: Życie religijne w Polsce pod okupacja 1939-1945. Metropolie wileńska i lwowska, zakony, ed. Z. Zieliński, Katowice 1992, p. 91-171.

\section{Journal articles}

„Na Rubieży” (1998), no. 30, p. 37.

Skórniak M., Kresowe pielgrzymki, „Spotkania Świrzan” (2007), no. 71, p. 34-36.

\section{Web sites}

Oberc Aleksander, www.web.archive.org/web/20080527201619/http://www.jaslanie.gal.pl/ o_slow.html (20.03.2013).

Ks. Aleksander Oberc, kapelan AK, www.katolicy.eu/PRL/Oberc.htm (20.03.2013).

M. Zalotyński, † Smaczniak Józef ps. Nadworny, www.mielec.rzochow.diecezja.tarnow.pl/ index.php?id=duszpasterze \&sub=Pochodz $\%$ C4\%85\& (20.03.2013).

Ks. Julian Rudnicki, działacz narodowy, www.katolicy.eu/ZSRR/Rudnicki\%20Julian.htm (21.03.2013).

Wspomnienie z życia ks. Franciszka Jastrzębskiego 1890-1962 (obszerne fragmenty), www. kresowianiezkuropatnik.republika.pl/wspomnienieks.html (21.03.2013). 